\title{
Video Recording as a Research Method for Investigating Children under Three Years of Age
}

\author{
Tuulikki Ukkonen-Mikkola \\ Tampere university \\ tuulikki.ukkonen-mikkola@tuni.fi \\ Juliene Madureira Ferreira \\ Tampere university \\ juliene.madureiraferreira@tuni.fi
}

\begin{abstract}
This paper explores the use of video recording as a method to investigate the under-three-year-old age group's interactions, learning, and development in kindergarten. Despite the continuous growth in the numbers of infants and toddlers attending early childhood education and care (ECEC) services in OECD countries, educational research focusing on children under three years of age is still scarce. One of the reasons for this scarcity is methodological, and this paper briefly addresses some issues for ECEC practitioners to reflect on in terms of toddlers as informants. The paper presents two different methods of video recording, points out issues concerning ethical procedures when video recording young children, and discusses ideas on what kinds of actions could be implemented in order to assure the participation of children in the research process.
\end{abstract}

Keywords: video recording, infants, toddlers, research method

\section{Introduction}

The latest OECD follow-up report highlights the increase in the numbers of infants and toddlers attending early childhood education and care (ECEC) services (OECD 2015). The report suggests this is indicative of the improving quality of ECEC. Nevertheless, at the same time as the numbers have grown, research has revealed that educators face more challenges in implementing pedagogical activities for young children (Davis, Torr, and Degotardi 2015). Practices have been developed based on teachers' beliefs, which have influenced how children experience opportunities for participation in ECEC contexts (Brownlee, Berthelsen, and Segaran 2009). Pedagogy for toddlers is under researched, as studies concerning ECEC settings tend to focus on older children and pre-schoolers (Sumsion and Harrison 2014). In addition, the developmental trajectories and learning of toddlers are often overlooked in na- 
tional curricula, resulting in an important information gap for this particular age group.

There are several reasons for the scarcity of research on children under three years of age, methodology being one of them. Qualitative educational research has historically used observations, interviews, field diaries, and document analysis to investigate different aspects of children's interaction, learning, and development, but when the child has not yet developed verbal communication, such methods of data collection become very limited. In this paper, we are particularly interested in discussing the challenges of participatory research with this age group and looking at how we can explore the use of video recording as the main method to investigate toddlers' interactions, learning, and development in ECEC contexts. We start by describing the characteristics of the data that can be gathered with video, then we present two different techniques that can be applied to video recording, and in sequence we discuss the analysis using a qualitative theoretical framework. To conclude, we discuss how the research in ECEC, particularly concerning toddlers, can be investigated through video analysis and point out the advantages and limitations of this method.

\section{Toddlers as Informants and Earlier Studies}

In this section, we describe some earlier studies concerning toddlers and the role of the ECEC teacher in toddler groups. In addition, we characterise toddlers as informants. The sensitivity and observation skills of educators are important in pedagogy and interaction with toddlers. Children's communication can be observed through verbal dialogues and/or non-verbal behaviours and activities (Bae 2009). Salomon, Sumsion, and Harrison (2017) have described the capacity of infants and toddlers to communicate using different kinds of facial expressions (e. g. smiles and crying) and other sophisticated emotional strategies as 'emotional capital.' Likewise, Clark (2005) emphasises the sensitivity of educators. He proposes that toddlers' non-verbal communication should be linked to everyday decision-making and pedagogy. In this way, children learn to understand and trust that these messages are taken into account in their daily activities. In addition, the observation skills of educators are important in pedagogy and interaction with toddlers.

Concerning the learning environments, younger children are often considered less capable of participation compared to their older peers (Smith 2002). The learning environment plays a significant role in pedagogy for toddlers, and Rutanen (2012) has emphasised the meaning of space and place in pedagogy and the learning environment. Rutanen (2014) has also implemented 
ethnographic studies on the learning environment of toddlers from the perspective of lived spaces using Lefebre's (1991) ideas. The data were gathered with video recording. The results indicate that the day care centre is an institution where the space is produced and reproduced by adults and toddlers using different approaches. Each actor participates in the production from particular starting points, experiences, and emotions. In addition, Rutanen (2012) states that children construct their lived space and relations to space through embodied, verbal, and non-verbal negotiations with their peers and upon the basis of observing the actions of others. In addition, toddlers negotiate the meanings related to their own space by defending their physical and symbolic territories and setting boundaries for actions.

Video recording can be used to reach out the children's perspective. For example, video recording has been used to investigate the infants' transition from home to day care (Dolby, Hughes, and Friezer 2014). Cameras were situated at floor level; sometimes the infants were filmed or sometimes the camera reflected the children's points of view. A step-by-step procedure was developed in this study that supported the infants' transition to day care and created a feeling of belonging to the children's group. Another way to gain the perspective of the infant is to use baby-cam. It is a small video camera that infants can wear at the side of their head on a hat. Baby-cam provide possibilities for infants to generate video-data from their own bodily position (Elwick 2015).

\section{Methods, Challenges, and Benefits of Video Recordings}

As opposed to using pre-existing videos as material to elicit specific behaviours or learning situations, here we discuss the use of video as a resource or tool to gather data and analyse the interactions, learning, and development of children under three years old. In this sense, video recordings are recognised as a potent source of information that provide a wide range of different kinds of observable elements, such as behaviours, actions, dynamics, materials, and dialogues. The data can be accessed countless times and understood within a time frame that allows the perception of continuity, sequence, and possible relations of cause and consequence (Pedrosa and Carvalho 2005).

According to Loizos (2008), the use of video recording becomes necessary 'whenever any set of human actions is too complex and difficult to be comprehensively described by a single observer as it unfolds' (p. 149). Teaching in the classroom, children's play, and specific situations of learning are highlighted by Loizos (2008) as examples of such complex sets of human action. 
Likewise, previous research applying video recordings to investigate small children's interactions (Lucena 2010; Ferreira 2017; 2018) points out that the ability to work with complexity is a major benefit of video recordings. Amorin, Dentz and Costa (2018) highlight the use of such a tool implies that we are looking at (1) multiple interactions at the same time; (2) interactions among peers in the same age group or different age groups, which impacts the type of communication established between children; (3) interactions between children and adults; and (4) interactions between children and materials in a certain space, affording different opportunities for learning and development. Ferreira (2017) shows that videos allow the complexity within interactive processes to be broken down into different dimensions, and by doing so, it is possible to address phenomena from different points of focus.

Therefore, the use of video recordings is appropriate when the researcher needs to analyse (i. e. treat the whole by relation to its single parts) the multiple aspects of a continuity of actions in order to understand the essence of the phenomenon he/she is investigating. It is not just a matter of the quantity of actions and participants (e.g. many children in the same play situation), but the many possible relations that such actions may constitute. Additionally, for the under threes, video recording can be an appropriate tool in studies that aim to give visibility to the children's wishes, intentions, reasoning, learning, and meaning-making process by means other than verbalisation. Through video recordings, it is possible to make explicit children's agency in play (Lucena 2010) or the leading role of children in adult-child play dynamics (Fantasia et al. 2014). As such, the analysis of children's interactions can be a potent tool for assessing children's development and the quality of learning processes in ECEC.

However, recognising the relevance of video recording as an interesting and appropriate tool is not enough. Knowledge on how to construct the data (what to record, when, how, and for how long) is what determines the efficacy of the method. Below, we give examples of two different techniques the mobile camera and the fixed, strategically positioned camera - and the justifications for their use.

The mobile camera is recommended for the apprehension of specific events in which the occurrences can be programmed and clearly followed (e.g. a specific situation of play, the interaction of a specific pair or group of children, the teacher's instructions for a particular activity). The ability to move the camera during the event allows the researcher to focalise particular aspects of the event and collect the type of information that he/she is looking for. Ferreira, Mäkinen, and De Souza Amorim (2016) video recorded a 
child with an intellectual disability during pretend play. The ability to follow the child, record his movements across the playroom while interacting with other children, and capture the interaction from different angles provided evidence both for the interpretation of the use of space during the pretend play and the gesture dynamics that revealed the content of the communication. Therefore, the mobile camera allows the researcher to make decisions on what elements are most relevant to record during the process. This technique positions the researcher as an active tool-maker during the data collection (Rossetti-Ferreira et al. 2008) and demands a clear understanding and vision of what elements can best reveal the phenomenon being examined.

On the other hand, the use of the mobile camera challenges the skill of the camera operator, as the constant movement and rapid change of focus can result in poor quality images and sound. Other issues should also be considered, such as the weight and price of the equipment. Appropriate equipment is required for high quality images, which can be heavy to carry and/or very expensive.

The fixed camera allows the researcher to record (1) events that are not programmable (e.g. the free play of children outside); (2) events involving several participants at the same time who all have equal relevance to the study (e. g. the teacher's interaction with the group); and (3) situations where no particular focus is yet defined. Additionally, the ability to leave the equipment operating independently allows the researcher to participate in the event or collect data with other methods simultaneously (e. g. a field diary). With a fixed camera, it is also possible for the researcher to make decisions during the recording; however, there are limitations concerning the adjustments that the equipment and its position in the environment allows, and this should be tested before the data collection starts. For example, if the study involves following how children use different toys and spaces, it is necessary to make sure the camera can reach all the areas in focus. The fixed camera is limited in terms of angles, and the researcher might lose sight of a specific subject depending on the setting.

Vasconcelos and Rossetti-Ferreira (2004) also argue that the positioning of the camera reveals the phenomenon from a specific point of view or through the perspective of the researcher looking at the phenomenon. Therefore, it is important to consider that all the distinctions the researcher can make of children's interactions, gestures, eye contact, and vocalisations are constituted by a specific point of view that generated a framing of the event. 
When considering these issues before planning the data collection, the researcher should also keep in mind that not all the images captured will be used in the study, especially when using the fixed camera. Due to the dynamics and speed of image apprehension, this technique provides a large volume of information that may or may not be relevant to the study. Therefore, the time saved by being able to let the camera run independently (not demanding the presence of the researcher during the recording itself) is added in the following phase of preparing the data for analysis. Data preparation (i. e. editing and selecting images based on pre-established criteria on the nature of the phenomenon, the theoretical reference adopted, and the research questions) will then be essential and more laborious for the researcher.

With both the mobile camera and the fixed camera, there are two considerations that should be highlighted. The first is related to the camera operator. In situations where the equipment operator is not the researcher him/herself, the researcher in charge should consider using techniques that demand less decision-making during the data collection or training the person collecting the data on the specific features of the event being examined. Likewise, if the operator is the researcher him/herself, proper training on the use of the equipment might be necessary. Therefore, although the quality of the image and sound are directly related to the quality of the equipment, it should also be considered that other aspects play a role, such as the skill of the operator, the arrangement of cameras and furniture in the environment, the lighting, the number of cameras required for the environment, etc.

Another consideration is related to the time and duration of the video recordings. For both techniques, the time of the filming must be planned according to the nature of the phenomenon and the frequency of its occurrence; and these factors must be constantly reconsidered by evaluating the quality of the images and sounds captured in terms of technical and conceptual aspects. In any case, the schedule of the video recordings must also factor in two preparatory stages: (1) time to adjust or become familiar with the environment and the equipment, and (2) time to build a rapport with the participants, allowing them to become familiar with the researcher and the equipment. Familiarisation with the equipment is essential to obtain quality images and sounds; the equipment must be adjusted and tested at the beginning of each recording session so that the data can be effectively used in the research. If the researcher is not the operator of the equipment, a pilot recording is suggested. The pilot recording serves as a test to find the optimal angles and the correct light and sound levels, but it also enables the researcher to sharpen his/her view regarding the object of the research within 
the framework adopted, thus making it possible to guide the operator in capturing the most useful material.

When considering the time required to build a rapport with the research participants (Olson and Peytchev 2007; Guillemin and Heggen 2009), one must also remember that people can change their behaviour in front of cameras or when they are observed. Participants - in this case especially the teacher, care takers, and other adults - may act according to what they believe to be the researcher's expectations in the study, or they may present very formal behaviours, harming the unveiling of the phenomenon. Thus, the researcher can be seen as a disturbing factor in the daily routine, and the camera itself can be an element that arouses the children's curiosity.

\section{Ethical Considerations}

Ethical questions must be carefully addressed when investigating young children. There are challenges in terms of balancing openness and the rights to anonymity and privacy - how does one obtain permission for the research from the young participants? In addition, there are ethical challenges concerning video data that present images of children and their environments. Respecting the informants and their relativities is also significant issue (Rutanen et al. 2018). These challenges are considered by local (university-level) and national ethics committees in many countries. The committees have based their norms on the Code of Nuremberg ( $\mathrm{NIH}$ 1947). However, there have been a number of culturally specific and complex interpretations (Alasuutari \& Alasuutari 2012). Ultimately, the implementation of research ethics seeks to ensure research that guarantees the protection of the informants (Rutanen et al. 2018).

When investigating toddlers, consent must be sought from the parents, and if the research is carried out in early childhood education settings, from the municipality, the ECEC director, and the educators. Naturally, the opinion of the children involved is important, and this point is challenging especially with young children (Alasuutari 2005). Nevertheless, the dialogue between researchers and the research participants is important in all aspects of the research (Rutanen et al. 2018).

A further significant ethical issue is how materials are shared with national and international research groups. Diverse cultural contexts and different ethical concepts and interpretations can cause tension between researchers from different countries. Therefore, more discussion and dialogue concerning the ethics of video research is needed among researchers, both locally and internationally (Rutanen et al. 2018). 


\section{Discussion and Conclusions}

In this paper, we reflected on the use of video recording as a method to investigate toddlers. We described some earlier studies, presented different ways using video recording, and highlighted the method's benefits and challenges. In addition, we reflected on the ethical considerations of video recording young children.

Video recording is versatile research method, albeit on with some restrictions. We have offered some examples of video recording; however, there are many other opportunities to utilise the method. One interesting alternative is letting children video record by themselves. This paper has briefly addressed some of the benefits and challenges of video recordings as tool for data collection. One benefit is that the method provides very detailed data that can be reused and re-analysed from different points of view. The potential down sides are the ethical questions raised, the huge amount of data produced, and the time required for transcriptions and analysis. Despite these challenges, we argue that video recording is a very useful method for gathering exact data on the learning, relationships, and interaction of young children (Rutanen 2012; 2014). Pedagogy for infants and toddlers is a very significant area in the field of ECEC, partly because of the growth in the numbers of infants and toddlers attending ECEC services. This research and the related discussion are also important for ECEC professionals, since in some debates, even the role of the ECEC teacher in the infants' and toddlers' groups is questioned when the focus of the activities is taking care of children.

\section{References}

Alasuutari, M. 2005. 'Miten rakentaa vuorovaikutusta lapsen haastattelussa?' In Haastattelu, tutkimus, tilanteet ja vuorovaikutus, edited by J. Ruusuvuori and L. Tiittula, 145-162. Tampere: Vastapaino.

Alasuutari, P., and M. Alasuutari. 2012. 'The Domestication of Early Childhood Education Plans in Finland.' Global Social Policy 12 (2): 129-148.

Bae, B. 2009. 'Children's Right to Participate - Challenges in Everyday Interaction.' European Early Childhood Education Research Journal 17 (3): 391-406.

Brownlee, J., D. Berthelsen, and N. Segaran. 2009. 'Childcare Workers' and Centre Directors' Beliefs about Infant Childcare Quality and Professional Training.' Early Child Development and Care 179 (4): 453-475.

Clark, A. 2005. 'Listening to and Involving Young Children: A Review of Research and Practice.' Early Child Development and Care 175 (6): 489-505.

Davis, B., J. Torr, and S. Degotardi. 2015. 'Infants and Toddlers: How Visible Are They in the Early Years Learning Framework?' International Journal of Child Care and Education Policy 9 (12). https://doi.org/10.1186/s40723-015-0014-y 
Amorin, K. S., M. V. Dentz, and N. M. S. Costa. 2018. 'Videogravação nas Ciências Humanas: O dilema entre potencial da imagem e direito de preservação da identidade.' In Pesquisa aplicada em psicologia implicações éticas, edited by M. S. Leme, S. Cagnin, and S. A. S. Leite, 13-48. Campinas: Mercado de Letras.

Dolby, R., E. Hughes, and B. Friezer. 2014. 'Playspaces: Educators, Parents and Toddlers.' In Lived Spaces of Infant-Toddler Education and Care: Exploring Diverse Perspectives on Theory, Research and Practice, edited by L. Harrison and J. Sumsion, 89-102. New York: Springer.

Elwick, S. 2015. "'Baby-Cam" and Researching with Infants: Viewer, Image and (Not)Knowing.' Contemporary Issues in Early Childhood 16 (4): 322-338.

Fantasia, V., A. Fasulo, A. Costall, and B. López. 2014. 'Changing the Game: Exploring Infants' Participation in Early Play Routines.' Frontiers in Psychology 5 (522): 1-9.

Ferreira, J. M. 2017. 'Crianças com déficit intelectual e processos interacionais com pares na pré-escola: reflexões sobre desenvolvimento.' PhD Dissertation, University of Sao Paulo.

- 2018. 'Inclusive Early Childhood Education and the Role of Peer Interaction: Brazil and Finland in dialogue.' PhD Dissertation, Tampere University.

Ferreira, J. M., M. Mäkinen, and K. De Souza Amorim. 2016. 'Intellectual Disability in Kindergarten: Possibilities of Development through Pretend Play.' Procedia: Social and Behavioral Science 217:487-500.

Guillemin, M., and K. Heggen. 2009. 'Rapport and Respect: Negotiating Ethical Relations between Researcher and Participant.' Medicine, Health Care, and Philosophy 12 (3): 291-299.

Lefebre, H. 1991. The Production of Space. Malden, MA: Blackwell.

Loizos, P. 2008. 'Video, filme e fotografias como documentos de pesquisa.' In Pesquisa qualitativa com texto, imagem e som: um manual pràtico, edited by M. W. Bauer and G. Gaskell, 137-155. Petròpolis: Vozes.

Lucena, J. 2010. 'Examinando os processos de assimilação, transformação, construção e compartilhamento de cultura entre crianças de dois anos no ambiente de creche.' Master's Thesis, Federal University of Pernambuco.

$\mathrm{NIH}$. 1947. Nuremberg Code. https://history.nih.gov/research/downloads/ nuremberg.pdf

OECD. 2015. Starting Strong 4: Monitoring Quality in Early Childhood Education and Care. Paris: OECD.

Olson, K., and A. Peytchev. 2007. 'Effect of Interviewer Experience on Interview Pace and Interviewer Attitudes.' Public Opinion Quarterly 71:273-286.

Pedrosa, M. I., and A. M. A. Carvalho. 2005. 'Análise qualitative de epoódio de interacao: uma reflexao sobre procedimentose formas de uso.' Psicologia: Reflexao e Critica 18 (3): 431-442.

Rossetti-Ferreira, M. C., K. De Souza Amorim, A. P. Soares-Silva, and Z. Ramos 
De Oliveira. 2008. 'Desafios metodológicos na perspectiva da rede de significacoes.' Cadernos de Pesquisa 38 (133): 147-170.

Rutanen, N. 2012. 'Socio-Spatial Practices in a Finnish Daycare Group for 1- to 3-Year-Olds.' Early Years 32 (2): 201-214.

- 2014. 'Lived Spaces in a Toddler Group: Application pf Lefebvre's Spatial Triad.' In Lived Spaces of Infant-Toddler Education and Care: Exploring Diverse Perspectives on Theory, Research and Practice, edited by L. Harrison and J. Sumsion, 17-28. New York: Springer.

Rutanen, N., K. De Souza Amorim, H. Marwick, and J. White. 2018. 'Tensions and Challenges Concerning Ethics on Video Research with Young Children's Experiences from an International Collaboration among Seven Countries.' Video Journal of Education and Pedagogy 3 (7): 1-14.

Salomon, A., J. Sumsion, and J. Harrison. 2017. 'Infants Draw on "Emotional Capital" in Early Childhood Education Contexts: A New Paradigm.' Contemporary Issues in Early Childhood 18 (4): 362-374.

Smith, A. B. 2002. 'Interpreting and Supporting Participation Rights: Contributions from Sociocultural Theory.' International Journal of Children's Rights 10:73-88.

Sumsion, J., and L. Harrison. 2014. 'Infant and Toddler Play.' In The SAGE Handbook of Play and Learning in Early Childhood, edited by L. Brooker, M. Blaise, and S. Edwards, 206-318. Los Angeles: Sage.

Vasconcelos, C. R. F., and M. C. Rossetti-Ferreira. 2004. 'Criancas pequenas brincando em creche: a possibilidade de múltiplos pontos de vista.' In Rede de significacoes e o estudo do desenvolvimento humano, edited by M. C. Rossetti-Ferreira, K. De Souza Amorim, and A. P. Soares-Silva, 113-126. Carvalho: Artmed.

\section{Videosnemanje kot raziskovalna metoda za raziskovanje otrok, mlajših od treh let}

Članek obravnava uporabo videosnemanja kot metode preučevanja odnosov v skupini, učenja in razvoja v vrtcu pri otrocih, mlajših od treh let. Kljub vedno večjemu številu dojenčkov in malčkov, ki v državah OECD obiskujejo programe zgodnjega izobraževanja in nege, je še vedno malo raziskav, ki se osredotočajo na otroke do treh let starosti. Eden od razlogov za pomanjkanje takšnih raziskav je metodološki, zato pričujoči članek na kratko obravnava nekaj vprašanj pri obravnavi malčkov kot vira informacij. Članek predstavlja dve različni metodi videosnemanja, opozarja na etična vprašanja pri snemanju majhnih otrok in razpravlja o idejah o tem, katere vrste ukrepov bi bilo mogoče izvesti, da bi zagotovili sodelovanje otrok $v$ raziskovalnem procesu.

Ključne besede: videosnemanje, dojenčki, malčki, raziskovalne metode 